\title{
Impact of Inflation on Economic Growth in Pakistan
}

\author{
Ayesha Sultan $^{1}$, Faiza Maqbool Shah ${ }^{2}$
}

\begin{abstract}
The main point of this research is to study the existence of inflation economy growth relationship of Pakistan. It is, additional, to examine whether it support or hurts the economic growth in a consistent way or it acts in a different way in unusual levels. Panel time-series data for the period 2005-15 have been taken and analysis is made by applying the method of Co-relation and Linear Regression. A moderate and significant inflation rate and economic growth relationship has been found to be present in the economy of Pakistan. The result of this study shows that current inflation rate is dangerous to the growth of the economy after a firm threshold point. On the root of the analysis, it is suggested to the strategy makers and the State Bank of Pakistan to confine the inflation underneath the 8 percent point and to keep it steady. Thus that it may put forth its helpful impacts on economy growth of the economy.
\end{abstract}

Keywords: Inflation, Economic, Growth, Threshold Level of Inflation, Pakistan.

\section{Introduction}

High and continued economic growth with low down inflation is the essential purpose of the macroeconomic strategy makers. As a result, inflation has been of the most researched topics in macroeconomics for the last several years because it has severe suggestions for expansion and income allocation. What aspects settle on the inflation rates have also been broadly discussed all across the world. Inflation, by boost in collective demand is called 'demandpull inflation' whereas supply distress is supposed to cause 'cost-push inflation'. This is hypothetical to have a strong upbeat correlation with the output gap.

The connection connecting economic growth and inflation, on the other hand, depends on the state of the economy. High economic growth, with no boost in inflation, is possible if the possible output of the economy is increasing adequate enough to keep pace with demand. It is also possible if the real output is underneath the prospective output (i.e. negative output gap) and there is satisfactory additional competence presented to handle with the demand heaviness. When the real output becomes equivalent with the prospective output, there remains no additional competence and the economy is working on full employment level, every additional increase in enlargement comes at the price of intensifying inflation. If demand keeps on to nurture at this phase, and the creative competence does not spread out, there is a hazard of hurried enhance in general cost level in the long run without a few supplementary enlargement in the output. This stage of increasing inflation can have harsh penalty for the economy.

High inflation is forever associated with enlarged cost inconsistency, which can lead to improbability about the expectations effectiveness of investment projects. This shows the way to the further conventional investment judgment than would or else be the case. It will, eventually, leads to lesser levels of investment and economic growth. Inflation might also impact an economy's balance of payments by making its exports comparatively more expensive. Furthermore, inflation can work together with the tax system to upset borrowing and lending decisions. Firms possibly will have to distribute more possessions to commerce with the effects of inflation
Achieving stable economic growth is the goal of the nearly all countries. Due to the various factor that effect economic growth it has been nearly impossible to achieve such goal. The most essential subject of macroeconomic policy is rate of inflation and growth of economy. With many variables it can be stated that inflation is determinant Of economy growth (Barro, 1995). Nevertheless there is no apparent conclusion about the relation between inflation and economic growth. Researchers investigated about economic growth and inflation and came forward with few different observations.

\section{Problem Statement:}

The purpose of this study is to investigate the relation between inflation and economic growth and. Therefore at the end of this study following questions would be answered.

- Is there any significant relation is between inflation and economic growth? If so, is the relation is positive or negative?

\section{Research Question:}

- Is GDP has any influence on money supply in Pakistan?

- Is GDP has any influence on per capita income in Pakistan?

- Is exchange rate has any influence on per capita income in Pakistan?

- Is exchange rate has any influence on money supply in Pakistan?

\section{Significance of the Study}

The significance of the study is that inflation is major problem in Pakistan and affect people's daily life like income, purchasing power, literacy rate, money supply, etc and they all effect economic growth of Pakistan in some way and that further effect in country development. So it's important that we know how impact inflation has on economic growth and at what level of inflation we can positively manage our economic growth.

\section{Objective of the Study}

The objective of this study is to examine the impact of inflation on economic growth in Pakistan. 


\section{International Journal of Science and Research (IJSR) \\ ISSN (Online): 2319-7064}

Index Copernicus Value (2013): 6.14 | Impact Factor (2014): 5.611

\section{Limitation of the Study}

The focus of this study is only on Pakistan and limited to the year from 2004 to 2014. This study is only tries to see impact of inflation on economic growth in Pakistan by corelation and regression method.

\section{Literature Review}

Robert Pollin and Andhog Zhu (2005), study presents the new non-linear regression estimation of the relation involving inflation and economic growth for 80 countries over the period $1961-2000$. As a result it was found out that high inflation is linked with reasonable gains in GDP growth up to an approximately $15-18 \%$ inflation.

Sergii Pyko (2008), examines the growth and inflation relation for CIS countries for year 2001 to 2008 by using non-linear analysis.Result of this study shows that for positive economic growth it is important that to try and keep low inflation rate. It is best that inflation rate will remain at $8 \%$ for higher or stable economic growth otherwise it's not good for country's economic condition.

Vikesh Gokal and Sabrina Hanif (2004), purpose of this study was to found out whether there is any significant relation exists among inflation and economic growth. Using the data of 140 countries from year 1960 to 1998 with threshold effect method the study suggests that, if threshold level is above than inflation, there will be no effect of inflation on growth but if threshold level is lower than inflation, then inflation will have significantly negative effect on growth.

Manoel , Renee and Monaheng (2013), objective of this study is to explore the part of inflation in determining economic performance in sub-Saharan African countries, members of the SADC. The outcome, based on panel time series analysis and data from 1980 to 2009 , recommend that inflation was certainly unfavorable to enlargement in the region.

Parsanna , Gopakumar (2008) objective of this study is to investigate the linkage between inflation and growth in India by using cointegration and error correction model using data from Reserve Bank of India from year 1972-2007. The outcome of the study shows that there is a long run negative impact of inflation on growth rate in India. Inflation is destructive somewhat than useful to growth. These outcomes have vital strategy implications.

Brian Motley (1998) investigates the impact of inflation on real growth in a Solow growth model using information from a cross section of countries over a 30-year period of time. The benefit of using an abstract model is that it lowers the threat that the consequences will mirror data-mining. The outcome recommend that the 5\% drop in inflation from the 1970-80 would boost the expansion level of real GDP per head from 0.1 and $0.5 \%$.This impact would be significance between $15 \%$ and $140 \%$ of one year's income. Even the lesser of these projections would be superior than the majority estimates the expenses of bringing inflation downward.
Raul and Danilo (2011) examine the set of countries in which inflation above the threshold has negative effect on economic growth. Using facts from 124 countries and by applying panel smooth transition regression it is found that the projected threshold of the inflation level for developed countries is $4.1 \%$, while for non-developed countries it is $19.1 \%$. It is also mention that inflation has negative effect on economic growth when it is in close proximity to the point of threshold for developing economies. It is also found that by selecting a reduced set of emergent countries the inflation threshold cataract to $7.9 \%$.

Sani I (2012) re-examines the matter of the occurrence and the intensity of inflation threshold in the link among inflation and economic growth in Nigeria, applying three dissimilar modern present fitting measures for estimating the threshold intensity and implication, sarel's (1996)threshold model, khan and sehndagi (2001) and drukker et al (2005) from 2005 to 2012. Findings of this paper recommend that the threshold level of inflation above which inflation is contrary to expansion is estimated at $10.5-12 \%$ for Nigera. From the two threshold point model, this study did not come across adequate reasons to acknowledge the null- hypothesis of the super-neutrarlity of money, and as a result, recommend that there is a threshold level of inflation above which money is not super-neutral.

Pradana m, rathnayaka and tharangha (2013) examine the short and long run link between inflation and economic growth of three Asian countries from 1980 to 2010 by using co-integration and causality test. The result reveals that there is a long run and negative relation between inflation and economic growth in Sri Lanka while there in statistically significant relation between the variables of China and India, and it is also found that there is short run negative relation between inflation and economic growth. The causality test shows that there is a unidirectional causality that runs from the inflation to economic growth in China. The study also discusses the important policy implications of the result.

Henri (2011) goal is to analyze the link connecting money, inflation and economic growth by VAR model from 19602007. The study reveals that swell in money supply swell growth and that growth causes inflation; nevertheless, enhance in money supply does not essentially raise inflation.

Elias and Khairul (2012) purpose of this study is to investigate the existence of long run link between economic growth and inflation in Bangladesh. The method engaged in this paper is the Granger causality test and co integration test from 1978 to 2010. The result shows that there is no co integration relation between economic growth and inflation and causality test suggests that there is unidirectional causality is seen running from inflation to economic growth.

Oliver (2013) purpose is to evaluate the relationship among inflation and economic performance in Nigeria. It also evaluates the character and shape of connection among inflation and exchange rate along with interest rate over the period of 1979-2010 by using ordinary least squares model, it was found out that the inflation rate is negatively related to 


\section{International Journal of Science and Research (IJSR) \\ ISSN (Online): 2319-7064}

Index Copernicus Value (2013): 6.14 | Impact Factor (2014): 5.611

real GDP while exchange and interest rate are positively related to inflation rate.

Monoel (2010) purpose is to examine the part of deprived macroeconomic performance, in high inflation rate, in formative growth for four countries of Latin American countries from 1970-2007. The findings based on time series analysis, verify the variable proof which propose that inflation has an unfavorable impact to on economic growth in the region.

Abis Getachew (2013) intention is to assess the empirical relation between economic growth and inflation in Ethiopia for the period of 1992Q1-2010Q4. By using co-integration model (Granger and Johansen) it was found that there is positive long run relation among economic growth and inflation. Inflation intensity lower or higher than the threshold level of inflation has negative impact on economic growth, therefore monetary policy and fiscal policy synchronization is essential to maintain inflation at the threshold level.

Robert J (1995) purpose of this study is to assess the inflation impact on economic performance with data set of 100 countries from year 1960-1990. By using regression model it is found out that $10 \%$ increase in inflation per year decrease from 0.4 to $0.6 \%$ ratio of investment to GDP.

\section{Methodology}

This study is quantitative in nature and examines the causal relationship between economic performance and inflation in Pakistan for last ten years from 2004-2014. The models we use to investigate the impact or relationship between inflation and economic growth are co-relation co-efficient and regression method. Data used in this study is secondary and the sources of data collection for this study are internet. And the exact sources that are used for collecting data are
World Bank (online), State Bank of Pakistan (online) and Economic Trading (online).

\section{Null or Alternative Hypothesis:}

$\mathrm{H}_{0:}$ There is no relationship between GDP and money supply in Pakistan.

$\mathrm{H}_{\mathrm{A}}$ : There is a relationship between GDP and money supply in Pakistan.

$\mathrm{H}_{0 \text { : }}$ There is no relationship between GDP and income in Pakistan.

$\mathrm{H}_{\mathrm{A}}$ : There is a relationship between GDP and income in Pakistan.

$\mathrm{H}_{0 \text { : }}$ There is no relationship between exchange rate and money supply in Pakistan.

$\mathrm{H}_{\mathrm{A}}$ : There is a relationship between exchange rate and money supply in Pakistan.

$\mathrm{H}_{0 \text { : }}$ There is no relationship between exchange rate and income in Pakistan.

$\mathrm{H}_{\mathrm{A}}$ : There is a relationship between exchange rate and income in Pakistan.

\section{Theoretical Framework}

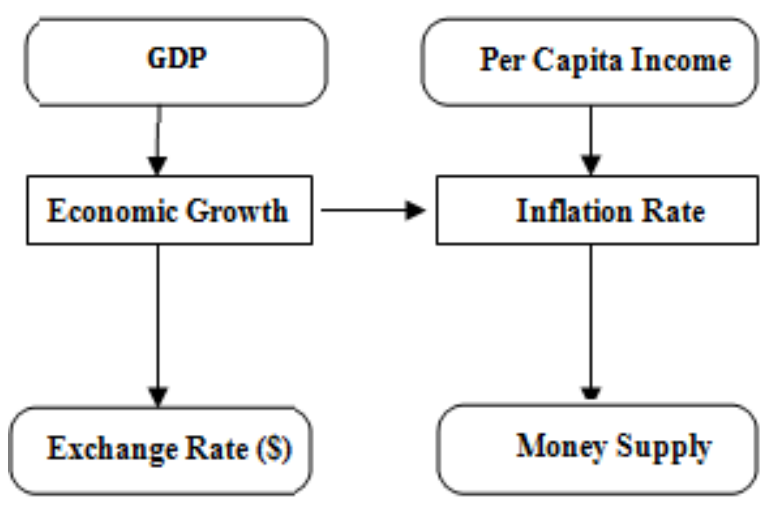

5. Data Analysis

\section{HYPOTHESIS NO 1: There Is no Relationship between GDP and Money Supply in Pakistan.}

\begin{tabular}{|c|c|c|c|}
\hline \multicolumn{4}{|c|}{ Correlations } \\
\hline \multicolumn{2}{|c|}{} & $\begin{array}{c}\text { GDP Rate } \\
(\%)\end{array}$ & $\begin{array}{c}\text { Money Supply } \\
\text { (PKR MILLION) }\end{array}$ \\
\hline \multirow{2}{*}{ GDP Rate (\%) } & Pearson Correlation & 1 & -0.281 \\
\cline { 2 - 4 } & Sig. (2-tailed) & & 0.432 \\
\cline { 2 - 4 } & $\mathrm{N}$ & 10 & 10 \\
\hline $\begin{array}{c}\text { Money Supply } \\
\text { (PKR MILLION) }\end{array}$ & Pearson Correlation & -0.281 & 1 \\
\hline & Sig. (2-tailed) & 0.432 & \\
\cline { 2 - 4 } & $\mathrm{N}$ & 10 & 10 \\
\hline
\end{tabular}

A Pearson's correlation was run to determine the relationship between GDP and Money supply. There was a weak negative correlation between GDP and Money supply, which was statistically significant $\left(\mathrm{r}_{\mathrm{s}}=-281, \mathrm{p}=.423\right.$ ). 


\section{International Journal of Science and Research (IJSR) \\ ISSN (Online): 2319-7064 \\ Index Copernicus Value (2013): 6.14 | Impact Factor (2014): 5.611}

\section{Regression:}

\begin{tabular}{|c|c|c|c|c|}
\hline \multicolumn{5}{|c|}{ Model Summary } \\
\hline Model & $\mathrm{R}$ & R Square & $\begin{array}{c}\text { Adjusted R } \\
\text { Square }\end{array}$ & $\begin{array}{c}\text { Std. Error of } \\
\text { the Estimate }\end{array}$ \\
\hline 1 & $.281^{\mathrm{a}}$ & .079 & -.036 & 2.0264 \\
\hline $\begin{array}{l}\text { a. Predictors: (Constant), MONEY } \\
\text { MILLION) }\end{array}$ & & & & \\
\hline
\end{tabular}

The study results reveal that there is a positive relationship between GDP and Money supply as depicted by coefficient of determination R of .281 and a correlation coefficient Rsquare of .079 . This means that change in money supply does influence on any change in GDP.

\begin{tabular}{|c|c|c|c|c|c|c|}
\hline \multicolumn{7}{|c|}{ ANOVA $^{b}$} \\
\hline \multicolumn{2}{|r|}{ Model } & $\begin{array}{l}\text { Sum of } \\
\text { Squares }\end{array}$ & $D f$ & $\begin{array}{l}\text { Mean } \\
\text { Square }\end{array}$ & $F$ & Sig. \\
\hline \multirow[t]{3}{*}{1} & Regression & 2.807 & 1 & 2.807 & 0.684 & $.432^{\mathrm{a}}$ \\
\hline & Residual & 32.849 & 8 & 4.106 & & \\
\hline & Total & 35.656 & 9 & & & \\
\hline & \multicolumn{6}{|c|}{$\begin{array}{l}\text { a. Predictors: (Constant), MONEY SUPPLY (PKR } \\
\text { MILLION) }\end{array}$} \\
\hline & b. Dep & ident Var & b & $\mathrm{DP} \mathrm{R}$ & $8 / 0$ & \\
\hline
\end{tabular}

From the ANOVA results, the probability value of .432 is obtained implying that it is greater than sig level of 0.05 which means that null hypothesis is fail to reject.

\begin{tabular}{|c|c|c|c|c|c|c|}
\hline \multicolumn{7}{|c|}{ Coefficients $^{\mathrm{a}}$} \\
\hline \multirow{2}{*}{\multicolumn{2}{|c|}{ Model }} & \multicolumn{2}{|c|}{$\begin{array}{l}\text { Unstandardized } \\
\text { Coefficients }\end{array}$} & \multirow{2}{*}{$\begin{array}{c}\text { Standardized } \\
\text { Coefficients } \\
\text { Beta }\end{array}$} & \multirow[b]{2}{*}{$\mathrm{T}$} & \multirow[b]{2}{*}{ Sig. } \\
\hline & & B & $\begin{array}{l}\text { Std. } \\
\text { Error }\end{array}$ & & & \\
\hline \multirow[t]{2}{*}{1} & (Constant) & 5.354 & 1.668 & & 3.209 & .012 \\
\hline & $\begin{array}{c}\text { Money } \\
\text { Supply } \\
\text { (PKR } \\
\text { MILLION) }\end{array}$ & $-1.765 \mathrm{E}-7$ & .000 & -.281 & -.827 & .432 \\
\hline & & ndent & bl & RATE & & \\
\hline
\end{tabular}

\section{Equation: GDP=5.345-1.765E-7MS}

One rupee increase in money supply will decrease the GDP on average by rupee $-1.765 \mathrm{E}-7 \mathrm{MS}$. And if money supply is zero than GDP will increase by 5.354 .

HYPOTHESIS NO 2: There Is no Relationship between GDP and Per Capita Income

\begin{tabular}{|c|l|c|c|}
\hline \multicolumn{2}{|l|}{ Correlations } & $\begin{array}{c}\text { GDP } \\
\text { RATE (\%) }\end{array}$ & $\begin{array}{c}\text { Per Capita } \\
\text { Income (bn) }\end{array}$ \\
\hline $\begin{array}{c}\text { GDP RATE } \\
(\%)\end{array}$ & $\begin{array}{l}\text { Pearson } \\
\text { Correlation }\end{array}$ & 1 & -.331 \\
\cline { 2 - 4 } & Sig. (2-tailed) & & .350 \\
\cline { 2 - 4 } & $\mathrm{N}$ & 10 & 10 \\
\hline $\begin{array}{c}\text { PER CAPITA } \\
\text { INCOME ( bn) }\end{array}$ & Pearson & -.331 & 1 \\
\cline { 2 - 4 } & Correlation & & \\
\cline { 2 - 4 } & Sig. (2-tailed) & .350 & \\
\hline
\end{tabular}

A Pearson's correlation was run to determine the relationship between GDP and Money supply. There was a moderate weak, negative correlation between GDP and per capita income which was statistically significant $\left(\mathrm{r}_{\mathrm{s}}=-.331\right.$, $\mathrm{p}=.350)$.

Regression
\begin{tabular}{|c|c|c|c|c|}
\hline Model Summary \\
\hline Model & $R$ & $R$ Square & $\begin{array}{c}\text { Adjusted } R \\
\text { Square }\end{array}$ & $\begin{array}{c}\text { Std. Error of } \\
\text { the Estimate }\end{array}$ \\
\hline 1 & $.331^{\text {a }}$ & .110 & -.002 & 1.9920 \\
\hline \multicolumn{2}{|c|}{ a. Predictors: (Constant), PER CAPITA INCOME ( bn) } \\
\hline
\end{tabular}

The study results reveal that there is a positive relationship between GDP and per capita income as depicted by coefficient of determination $\mathrm{R}$ of .331 and a correlation coefficient R-square of .110. This means that change in income per capita has a little influence on any change in GDP.

\begin{tabular}{|c|c|c|c|c|c|}
\hline \multicolumn{6}{|l|}{ ANOVA $^{b}$} \\
\hline Model & $\begin{array}{l}\text { Sum of } \\
\text { Squares }\end{array}$ & $\mathrm{df}$ & $\begin{array}{l}\text { Mean } \\
\text { Square }\end{array}$ & $\mathrm{F}$ & Sig. \\
\hline Regression & 3.911 & 1 & 3.911 & .986 & $.350^{\mathrm{a}}$ \\
\hline Residual & 31.745 & 8 & 3.968 & & \\
\hline Total & 35.656 & 9 & & & \\
\hline
\end{tabular}

From the ANOVA results, the probability value of .350 is obtained implying that it is greater than sig level of 0.05 which means that null hypothesis is fail to reject.

\begin{tabular}{|c|c|c|c|c|c|c|}
\hline \multicolumn{7}{|c|}{ Coefficients $^{\mathrm{a}}$} \\
\hline \multirow{2}{*}{\multicolumn{2}{|c|}{ Model }} & \multicolumn{2}{|c|}{$\begin{array}{l}\text { Unstandardized } \\
\text { Coefficients }\end{array}$} & \multirow{2}{*}{\begin{tabular}{|c|}
$\begin{array}{c}\text { Standardized } \\
\text { Coefficients }\end{array}$ \\
Beta \\
\end{tabular}} & \multirow[b]{2}{*}{$\mathrm{T}$} & \multirow[b]{2}{*}{ Sig. } \\
\hline & & $\mathrm{B}$ & Std. Error & & & \\
\hline \multirow[t]{2}{*}{1} & (Constant) & \begin{tabular}{|l|}
7.464 \\
\end{tabular} & 3.466 & & 2.153 & .063 \\
\hline & $\begin{array}{c}\text { PER } \\
\text { CAPITA } \\
\text { INCOME } \\
\text { (bn) }\end{array}$ & -.003 & .003 & -.331 & -.993 & .350 \\
\hline
\end{tabular}

\section{Equation: GDP $=7.464-.003 \mathrm{PCI}$}

One rupee increase in per capita income will decrease the GDP on average by rupee -.003PCI. And if per capita income is zero than GDP will increase by 7.464 .

HYPOTHESIS NO 3: There Is no Relationship between Exchange Rate (\$) and Money Supply in Pakistan.

\begin{tabular}{|c|c|c|c|}
\hline \multicolumn{4}{|c|}{ Correlations } \\
\hline \multicolumn{2}{|c|}{} & $\begin{array}{c}\text { Exchange } \\
\text { Rate (\$) }\end{array}$ & $\begin{array}{c}\text { Money Supply } \\
\text { (PKR Million) }\end{array}$ \\
\hline \multirow{2}{*}{$\begin{array}{c}\text { Exchange } \\
\text { Rate (\$) }\end{array}$} & $\begin{array}{c}\text { Pearson } \\
\text { Correlation }\end{array}$ & 1 & $.952^{* *}$ \\
\cline { 2 - 4 } & Sig. (2-tailed) & 10 & .000 \\
\cline { 2 - 4 } & $\mathrm{N}$ & $.952^{* *}$ & 10 \\
\hline $\begin{array}{c}\text { Money Supply } \\
\text { (PKR Million) }\end{array}$ & $\begin{array}{c}\text { Pearson } \\
\text { Correlation }\end{array}$ & & 1 \\
\cline { 2 - 4 } & Sig. (2-tailed) & .000 & \\
\cline { 2 - 4 } & $\mathrm{N}$ & 10 & 10 \\
\hline **. Correlation is significant at the 0.01 level (2-tailed). \\
\hline \multicolumn{4}{|c|}{}
\end{tabular}

\section{Volume 4 Issue 11, November 2015}




\section{International Journal of Science and Research (IJSR) \\ ISSN (Online): 2319-7064 \\ Index Copernicus Value (2013): 6.14 | Impact Factor (2014): 5.611}

A Pearson's correlation was run to determine the relationship between Exchange rate and Money supply. There was a strong uphill positive correlation between Exchange rate and Money supply, which was statistically significant $\left(\mathrm{r}_{\mathrm{s}}=-.952, \mathrm{p}=.000\right)$.

Regression
\begin{tabular}{|c|c|c|c|c|}
\hline \multicolumn{5}{|c|}{ Model Summary } \\
\hline Model & $R$ & $R$ Square & $\begin{array}{c}\text { Adjusted } R \\
\text { Square }\end{array}$ & $\begin{array}{c}\text { Std. Error of the } \\
\text { Estimate }\end{array}$ \\
\hline 1 & $.952^{\mathrm{a}}$ & .906 & .894 & 5.36083 \\
\hline a. Predictors: (Constant), MONEY SUPPLY (PKR MILLION) \\
\hline
\end{tabular}

The study results reveal that there is a positive relationship between exchange rate and money supply as depicted by coefficient of determination $\mathrm{R}$ of .952 and a correlation coefficient R-square of .906. This means that change in money supply does have influence on any change in exchange rate.

\begin{tabular}{|c|c|c|c|c|c|c|}
\hline \multicolumn{7}{|c|}{ ANOVA $^{b}$} \\
\hline \multicolumn{2}{|r|}{ Model } & $\begin{array}{c}\text { Sum of } \\
\text { Squares }\end{array}$ & $\mathrm{df}$ & $\begin{array}{l}\text { Mean } \\
\text { Square }\end{array}$ & $\mathrm{F}$ & Sig. \\
\hline \multirow[t]{3}{*}{1} & Regression & 2204.794 & 1 & 2204.794 & 76.719 & $.000^{\mathrm{a}}$ \\
\hline & Residual & 229.908 & 8 & 28.739 & & \\
\hline & Total & 2434.702 & 9 & & & \\
\hline \multicolumn{7}{|c|}{$\begin{array}{lllll}\text { a. Predictors: } & \text { (Constant), } & \text { MONEY } & \text { SUPPLY } & \text { (PKR } \\
\text { MILLION) } & & & \\
\end{array}$} \\
\hline
\end{tabular}

From the ANOVA results, the probability value of .000 is obtained implying that it is lesser than sig level of 0.05 which means that null hypothesis is rejected.

\begin{tabular}{|c|c|c|c|c|c|c|}
\hline \multicolumn{7}{|c|}{ Coefficients $^{\mathbf{a}}$} \\
\hline \multirow{2}{*}{\multicolumn{2}{|c|}{ Model }} & \multicolumn{2}{|c|}{$\begin{array}{c}\text { Unstandardized } \\
\text { Coefficients } \\
\end{array}$} & \multirow{2}{*}{\begin{tabular}{|c|}
$\begin{array}{c}\text { Standardized } \\
\text { Coefficients }\end{array}$ \\
Beta \\
\end{tabular}} & \multirow[b]{2}{*}{$\mathrm{t}$} & \multirow[b]{2}{*}{ Sig. } \\
\hline & & B & $\begin{array}{l}\text { Std. } \\
\text { Error }\end{array}$ & & & \\
\hline \multirow[t]{2}{*}{1} & (Constant) & 44.335 & 4.414 & & 10.045 & .000 \\
\hline & $\begin{array}{c}\text { MONEY } \\
\text { SUPPLY (PKR } \\
\text { MILLION) }\end{array}$ & \begin{tabular}{|c|}
$4.946 \mathrm{E}-$ \\
6
\end{tabular} & .000 & .952 & 8.759 & .000 \\
\hline \multicolumn{7}{|c|}{ a. Dependent Variable: EXCHANGE RATE (\$) } \\
\hline
\end{tabular}

Equation: $\mathrm{ER}=44.335+4.946 \mathrm{E}-6 \mathrm{MS}$

One rupee increase in money supply will increase the exchange rate on average by rupee 4.946E-6. And if money supply is zero than exchange rate will increase by 44.335 .

HYPOTHESIS NO 4: There is no Relationship between Exchange rate (\$) and Per Capita Income in Pakistan.

\begin{tabular}{|c|c|c|c|}
\hline \multicolumn{4}{|c|}{ Correlations } \\
\hline & & $\begin{array}{c}\text { Exchange } \\
\text { Rate }(\$)\end{array}$ & $\begin{array}{c}\text { Per Capita } \\
\text { Income } \\
\text { (bn) }\end{array}$ \\
\hline \multirow{3}{*}{$\begin{array}{c}\text { EXCHANGE } \\
\text { RATE (\$) }\end{array}$} & Pearson Correlation & 1 & $.947^{* *}$ \\
\hline & Sig. (2-tailed) & & .000 \\
\hline & $\mathrm{N}$ & 10 & 10 \\
\hline \multirow{3}{*}{$\begin{array}{c}\text { PER CAPITA } \\
\text { INCOME } \\
(\text { bn })\end{array}$} & Pearson Correlation & $.947^{* *}$ & 1 \\
\hline & Sig. (2-tailed) & .000 & \\
\hline & $\mathrm{N}$ & 10 & 10 \\
\hline
\end{tabular}

Pearson's correlation was run to determine the relationship between Exchange rate and Per Capita Income. There was a strong uphill positive correlation between Exchange rate and Money supply, which was statistically significant $\left(\mathrm{r}_{\mathrm{s}}=-.947\right.$, $\mathrm{p}=.000)$.

\section{Regression}

\begin{tabular}{|c|c|c|c|c|}
\hline \multicolumn{5}{|c|}{ Model Summary } \\
\hline Model & $\mathrm{R}$ & R Square & $\begin{array}{c}\text { Adjusted R } \\
\text { Square }\end{array}$ & $\begin{array}{c}\text { Std. Error of the } \\
\text { Estimate }\end{array}$ \\
\hline 1 & $.947^{\mathrm{a}}$ & .898 & .885 & 5.58482 \\
\hline \multicolumn{5}{|c|}{ a. Predictors: (Constant), PER CAPITA INCOME ( bn) } \\
\hline
\end{tabular}

The study results reveal that there is a positive relationship between exchange rate and money supply as depicted by coefficient of determination $\mathrm{R}$ of .947 and a correlation coefficient R-square of 898. This means that change in money supply does have influence on any change in exchange rate.

\begin{tabular}{|c|c|c|c|c|c|c|}
\hline \multicolumn{7}{|c|}{ ANOVA $^{b}$} \\
\hline \multicolumn{2}{|r|}{ Model } & $\begin{array}{l}\text { Sum of } \\
\text { Squares }\end{array}$ & $d f$ & $\begin{array}{l}\text { Mean } \\
\text { Square }\end{array}$ & $F$ & Sig. \\
\hline \multirow[t]{3}{*}{1} & Regression & 2185.181 & 1 & 2185.181 & 70.060 & $.000^{\mathrm{a}}$ \\
\hline & Residual & 249.522 & 8 & 31.190 & & \\
\hline & Total & 2434.702 & 9 & & & \\
\hline & $\begin{array}{l}\text { dictors: (C } \\
\text { pendent V }\end{array}$ & $\begin{array}{l}\text { onstant), } \mathrm{P} \\
\text { ariable: EX }\end{array}$ & $\begin{array}{l}\mathrm{ER} \\
\mathrm{CH}\end{array}$ & $\begin{array}{l}\text { CAPITA I } \\
\text { ANGE RA }\end{array}$ & $\begin{array}{l}\text { COMI } \\
\mathrm{E}(\$)\end{array}$ & \\
\hline
\end{tabular}

\section{Interpretation}

From the ANOVA results, the probability value of .000 is obtained implying that it is lesser than sig level of 0.05 which means that null hypothesis is rejected.

\begin{tabular}{|c|c|c|c|c|c|c|}
\hline \multicolumn{7}{|c|}{ Coefficients $^{\mathrm{a}}$} \\
\hline & \multirow[b]{2}{*}{ Model } & \multicolumn{2}{|c|}{$\begin{array}{c}\text { Unstandardized } \\
\text { Coefficients }\end{array}$} & \multirow{2}{*}{\begin{tabular}{|c|}
$\begin{array}{l}\text { Standardized } \\
\text { Coefficients }\end{array}$ \\
Beta \\
\end{tabular}} & \multirow[b]{2}{*}{$\mathrm{t}$} & \multirow[b]{2}{*}{ Sig. } \\
\hline & & B & Std. Error & & & \\
\hline \multirow[t]{2}{*}{1} & (Constant) & .041 & 9.718 & & .004 & .997 \\
\hline & $\begin{array}{l}\text { PER CAPITA } \\
\text { INCOME ( bn) }\end{array}$ & .075 & .009 & .947 & 8.370 & .000 \\
\hline
\end{tabular}

Equation: $\mathrm{ER}=.041+.075 \mathrm{PCI}$

One rupee increase in per capita income will increase the exchange rate on average by rupee .075 PCI. And if per capita income is zero than exchange rate will increase by .041 .

\section{Findings}

From the above analysis, by using co-efficient and linear regression model it is found out that null hypothesis 1 and 2 is fail to reject which means there is no relationship between GDP and Money supply in Pakistan same in the case with GDP and Per capita income relationship while null hypothesis 3 and 4 is rejected which means there is a relationship between Exchange rate (\$) and Money supply in Pakistan and there is also a relationship between Exchange rate $(\$)$ and Per capita income in Pakistan.

Null-Hypothesis No 1: Fail To Reject.

\section{Volume 4 Issue 11, November 2015}




\section{International Journal of Science and Research (IJSR) \\ ISSN (Online): 2319-7064}

Index Copernicus Value (2013): 6.14 | Impact Factor (2014): 5.611

Null-Hypothesis No 2: Fail To Reject.

Null-Hypothesis No 3: Reject.

Null-Hypothesis No 4: Reject.

With above results of null-hypothesis it is establish that there is a moderate relationship between inflation rate and economic growth in Pakistan because two of null hypothesis is rejected but the other two null-hypothesis is accepted which shows that there is a slightly moderate and significance relationship between inflation and economic growth in Pakistan.

\section{Conclusion}

Achieving stable economic growth is the goal of the nearly all countries. Due to the variety of issues that effect economic growth it has been nearly impossible to achieve such goal. The most essential subject of macroeconomic policy is rate of inflation and growth of economy (Barro, 1995).

This study is about the relationship between inflation and economic growth in Pakistan. The significance of the study is that inflation is major problem in Pakistan and affect people's daily life like income, purchasing power, literacy rate, money supply, etc and they all cause different effect on economic growth of Pakistan in some way and that further effect in country development. So it's important that we know how much of a impact inflation has on economic growth. This paper examines the impact of inflation rate on economic growth in Pakistan by using Co-efficient Corelation method and Linear Regression method over the period of 2005-2014. The results fail to reject the first two null-hypothesis of this research while last two nullhypothesis of this research is rejected because of these result it is establish that there is a moderate and significant relationship between inflation rate and economic growth in Pakistan

\section{Recommendation}

On the foundation of this research, it can be suggested to maintain the inflation rate underneath the point of 8 percent in the economy. Thus, the strategy makers and the State Bank of Pakistan should give attention to on those options which keep the inflation rate steady and underneath the point which has been found the useful for accomplishment of steady economic growth. Modest and constant inflation is also useful for diminishing the fluctuations and doubts in the financial sector of economy, which, in turn, increase the assets development behavior in the country. Thus that it may possibly put forth its encouraging effects on the economy. Therefore, sustained price constancy will eventually be the finest strategy suggestion to steady and constant economic growth of the economy.

\section{References}

[1] Barro, R. J. (1990). Inflation and Economic Growth. Cambridge.

[2] Bittencourt, M. (2011). Inflation and Economic Growth. Latin America. Data, W. B.
[3] Doguwal, S. I. (2005). Inflation and Economic Growth. Nigeria.

[4] Dr. Md. Elias Hossain, B. C. (2010). Inflation and Economic Growth. Bangladesh.

[5] Galrao, J. R. (2001). Does high Inflation effect Growth in long and short run. Australia and Brazil.

[6] Gopukumar, P. V. Inflation and Economic Growth. India.

[7] Hanif, V. G. (2004). Relationship Between Inflation and Economic Growth. fiji.

[8] Inyiama, O. I. (2013). Does Inflation weaken Economic Growth. Nigeria.

[9] Kapila, P. M. (2012). Testing the link between Inflation and Economic Growth. China.

[10] Li, M. (2004). Inflation and Economic Growth. Canada.

[11] Makuria, A. G. (2013). Relationship between Inflation and Economic Growth. South Africa.

[12] Mamo, F. T. (2012). Economic Growth and Inflation. Sodertons Max Gillman, M. H. Inflation and Growth. Paris.

[13] Motley, B. (1994). Growth and Inflation. San Francisco.

[14] Mustafa Caglayan, O. K. (2012). The impact of Inflation Uncertainity on Economic. UK. Pakistan, S. B.

[15] Pyko, S. (2008). Inflation and Economic Growth. kyiv.

[16] Tabi, H. N. (2010). Inflation Money and Economc Growth. Cameroon.

[17] Trupkin, R. I. (2011). Relationship between Inflation and Economic Growth. Mexico.

[18] Van, M. B. (2013). Inflation and Economic Growth. South Africa.

[19]Zhu, R. P. (2005). Inflation and Economic Growth. Amherst and China. 